\title{
Role of neural barriers in the pathogenesis and outcome of Streptococcus pneumoniae meningitis (Review)
}

\author{
OFER PRAGER $^{1,2}$, ALON FRIEDMAN ${ }^{1-3}$ and YAFFA MIZRACHI NEBENZAHL ${ }^{4}$ \\ ${ }^{1}$ Department of Physiology and Cell Biology, Faculty of Health Sciences, \\ Ben-Gurion University of The Negev, Beer-Sheva 84101; ${ }^{2}$ Cognitive \& Brain Sciences, \\ The Zlotowski Center for Neuroscience, Ben-Gurion University of The Negev, Beer-Sheva 84105, Israel; ${ }^{3}$ Department of \\ Medical Neuroscience, Faculty of Medicine, Dalhousie University, Halifax, NS B3H 4R2, Canada; \\ ${ }^{4}$ The Shraga Segal Department of Microbiology, Immunology and Genetics, Faculty of Health Sciences, \\ Ben-Gurion University of The Negev, Beer-Sheva 84101, Israel
}

Received September 28, 2016; Accepted November 10, 2016

DOI: $10.3892 /$ etm.2017.4082

\begin{abstract}
Bacterial meningitis is an inflammatory disease of the meninges of the central nervous system (CNS). Streptococcus pneumoniae (S. pneumoniae), Neisseria meningitidis, and Haemophilus influenzae are the major bacterial pathogens causing meningitis with $S$. pneumoniae being responsible for two thirds of meningitis cases in the developed world. To reach the CNS following nasopharyngeal colonization and bacteraemia, the bacteria traverse from the circulation across the blood brain barrier (BBB) and choroid plexus. While the BBB has a protective role in healthy individuals by shielding the CNS from neurotoxic substances circulating in the blood and maintaining the homeostasis within the brain environment, dysfunction of the BBB is associated with the pathophysiology of numerous neurologic disorders, including bacterial meningitis. Inflammatory processes, including release of a broad range of cytokines and free radicals, further increase vascular permeability and contribute to the excessive neural damage observed. Injury to the cerebral microvasculature and loss of blood flow auto-regulation promote increased intracranial pressure and may lead to vascular occlusion. Other common complications commonly associated with meningitis include abnormal neuronal hyper-excitability (e.g., seizures) and loss of hearing. Despite the existence of antibiotic treatment and adjuvant therapy, the relatively high mortality rate and the severe outcomes among survivors of pneumococcal meningitis in developing and developed countries increase the urgency in the requirement of discovering novel biomarkers
\end{abstract}

Correspondence to: Professor Yaffa Mizrachi Nebenzahl, The Shraga Segal Department of Microbiology, Immunology and Genetics, Faculty of Health Sciences, Ben-Gurion University of The Negev, P.O. Box 151, Ben Gurion Avenue, Beer-Sheva 84101, Israel E-mail:ymizr@bgu.ac.il

Key words: S. pneumoniae, meningitis, central nervous system, blood brain barrier, pathogenesis, virulence factors, innate immunity, inflammation for the early diagnosis as well as novel treatment approaches. The present review aimed to explore the changes in the brain vascular barriers, which allow $S$. pneumoniae to invade the $\mathrm{CNS}$, and describe the resultant brain injuries following bacterial meningitis.

\section{Contents}

1. Introduction

2. Pneumococcal invasion of the CNS

3. Immune response and neuro-inflammatory mechanisms following CNS invasion

4. Immune residents of the brain-microglia and astrocytes

5. Brain injury following pneumococcal invasion

6. Summary

\section{Introduction}

Streptococcus pneumoniae Meningitis. Despite the implementation of childhood vaccination schemes and the availability of effective antibacterial agents, bacterial meningitis remains to affect individuals in developing and developed countries. Meningitis is a central nervous system (CNS) infection often associated with severe outcomes and significant long-term effects in a substantial number of survivors. This disease thus requires prompt diagnosis and treatment (1). Complications may be sudden or gradual in onset and may arise anytime after the appearance of initial symptoms, including the time after completion of therapy. Symptoms of meningitis include fever, headache, confusion and vomiting, often preceded by symptoms of an upper respiratory tract infection. Clinical features used for diagnosis include cerebrospinal fluid (CSF) pleocytosis with predominance of neutrophils, elevated CSF protein, decreased CSF glucose and isolation of the bacteria from the CSF by culture. S. pneumoniae, Neisseria meningitidis and Haemophilus influenzae are the major bacterial pathogens causing meningitis with $S$. pneumoniae being responsible for two thirds of meningitis cases in the developed world (1). 
S. pneumoniae is a Gram-positive pathogen, which colonizes the nasopharyngeal mucosa of children as well as adults and is transferred among individuals by coughing and sneezing (for review, see 2). In addition to meningitis, S. pneumoniae causes a broad spectrum of diseases, including otitis media, pneumonia and bacteremia (2), leading to substantial morbidity and mortality worldwide. Mortality due to pneumococcal meningitis ranges between 15 and $40 \%$, while $~ 50 \%$ of survivors experience long-term health effects. Of note, even after a good recovery, neuropsychological testing demonstrates cognitive impairment in approximately one third of survivors $(3,4)$. Vaccination with the pneumococcal conjugate vaccine has reduced pneumococcal invasive diseases caused by the serotypes included in the vaccine, but this reduction has been offset by increases of carriage and disease caused by strains not included in the vaccine formulation $(2,5,6)$. The following review highlights the underlying mechanisms of neural complications following CNS invasion of S. pneumoniae.

Colonization. The pneumococcus habitat is the human nasopharynx mucosa with a prevalence of $\sim 40 \%$ in infants and $15 \%$ in adults (7). The bacterium is transferred between individuals mainly by coughing and sneezing. Once in the niche, bacterial survival depends on adherence, nutrition and replication; the pneumococcus has to overcome the host's immune system as well as other microbial species that can colonize the same niche (8). Two types of pili identified in S. pneumoniae are responsible for initial attachment of the bacterium to the host. The first pilus is an oligomeric appendage encoded by the rlrA operon (9) and the second pilus is encoded by pilus islet 2 (10). To reach the epithelial cell layer and colonize the nasopharynx, S. pneumoniae degrades the mucus by exoglycosidases such as neuraminidase $\mathrm{A}$, $\beta$-galactosidase, $\beta$ - $N$-acetylglucosaminidase and neuraminidase $\mathrm{B}$, decreasing mucus viscosity and preventing mucus entrapment (11). In addition, it produces pneumolysin, a toxin that decreases epithelial cell cilia beating and enhances bacterial adherence (12). Pneumococcus also expresses the enzymes $\mathrm{N}$-acetylglucosamine-deacetylase A and $O$-acetyltransferase that provide resistance to lysozyme that cleaves the peptidoglycan in the cell wall of the pathogen (13). To compete with the host innate immune system at the nasopharynx site, the pneumococcus has developed several strategies: i) Encapsulation and the use of proteases which prevent binding of secretory immunoglobulin (Ig) A and cleave IgA antibodies, immune system components designed to facilitate phagocytosis of the bacteria (14). ii) Inhibition of the activity of Lactoferrin, an iron-binding glycoprotein, thus enabling the utilization of iron, which is necessary for the bacteria's metabolism (15). iii) Limitation of the activation of the complement cascade which normally promotes the cleavage of several complement factors, leading to bacterial opsonization and phagocytosis, leukocyte recruitment and creation of pores in the pathogen's membrane, thus inducing cell lysis $(6,16)$.

Following the initial attachment, adhesive molecules embedded in the bacterial cell wall or the cytoplasmic membrane are exposed as a result of shedding of the capsule (17). Among these adhesins are: The lipoprotein pneumococcal surface adhesin A (18) which binds to the E-cadherin receptor (19); the Pneumococcal adherence and virulence factor (Pav)-A protein, which binds to the extracellular matrix protein fibronectin to produce a Pav-A-finbronectin complex that binds an integrin receptor $(20,21)$; fructose bisphosphate aldolase $(22,23)$, which was found to bind the flamingo cadherin receptor and NADH oxidase, which was found to bind, among others, laminin $\alpha 5$ and contactin 4 (24). Recently, Pav-B and CbpA (CbpA, also known as PspC) were found to have an important role in the interaction of $S$. pneumoniae with matricellular glycoprotein thrombosphondin-1, a mediator of bacterial adhesion to host cells (25).

After binding, S. pneumoniae interacts with additional adhesins. These include phosphorylcholine, which binds to the platelet activating factor receptor (PAF-R), CbpA (26) which binds to either the polymeric Ig receptor (pIgR) or to secretory IgA (21). The latter two adhesins are considered invasins, since they facilitate transcytosis through the mucosal epithelial cell layer from the apical membrane to the basal membrane using the PAF-R and $\mathrm{pIgR}$ recycling pathways (27). Binding and crossing the epithelial cell layers allows access to the submucosal layer, leading to invasive illness.

Bacteraemia. During the bacteremic phase, the pneumococcus reaches and aims to survive in the bloodstream. In the blood, the pneumococcus confronts additional host defense mechanisms, the first line of defense being complement-mediated opsonization and phagocytosis. To survive, the pneumococcus increases its capsule size, reduces complement deposition on its surface and limits subsequent interaction with phagocytes $(28,29)$. This is achieved by bacterial surface proteins that target specific complement components, thus inhibiting complement-mediated clearance, e.g., by recruiting factor $\mathrm{H}$ that inhibits the complement cascade $(30,31)$. The second line of defense is recognition of the bacteria by antigen-presenting cells through the binding of pattern recognition receptors directed specifically toward general motifs of molecules expressed by the pathogen. This results in release of cytokines such as tumor necrosis factor alpha (TNF- $\alpha$ ), interleukin (IL)-1 and IL-6 that further induce the recruitment of neutrophils and lymphocytes, and simultaneously cause cerebrovascular damage (32). A prominent risk resulting in vascular injury is exposure of blood to an extravascular tissue factor and activation of the coagulation cascade that may lead to vascular clot formation $(33,34)$, BBB dysfunction and blood flow impairment (35).

\section{Pneumococcal invasion of the CNS}

A high amount of bacteria in the blood circulation is thought to be required for CNS invasion, and is thus considered as a risk factor for the development of meningitis. Bacteraemia allows the pneumococcus to cross the cerebral endothelium or the choroid plexus epithelium and enter the CNS. Although the blood-CSF barrier and the BBB protect the brain and meningeal space from pathogen attacks, pneumococci have developed mechanisms to overcome this obstacle.

Blood-CNS barriers. The cellular components of the neurovascular unit use a combination of chemical and electrical signals to communicate. Proper neuronal signaling depends on precise ionic concentrations; thus, it is essential to maintain 
a stable microenvironment within the neuropil. Three barrier layers limit and regulate molecular exchange at the interfaces between the blood and neural tissue: i) The BBB at the level of cerebrovascular endothelial cells; ii) the blood-CSF barrier at the choroid plexus epithelium in the ventricles; and iii) the arachnoid-membrane barrier, which underlies the dura and envelopes the brain. All three barriers apply a combination of a physical barrier (tight junctions between cells reducing flux through intercellular pathway), a transport barrier (transport mechanisms mediating solute flux) and a metabolic barrier (enzymes metabolizing molecules in transit) (36). The BBB, first described by Goldman (37), exerts the most significant control over the immediate microenvironment of brain cells. It bestows the blood vessels in the CNS with unique properties that tightly regulate the movement of molecules, ions and cells between the blood and the neural tissue. Due to the presence of tight junctions between adjacent endothelial cells which limit para-cellular passage, trafficking across an intact BBB is mostly trans-cellular (through carriers and vesicular systems) (for review see 37-39). An additional route of entry for small lipophilic agents are lipid membranes, through which small gaseous molecules, including oxygen and carbon dioxide, can diffuse freely. Trans-cellular traffic of small hydrophilic molecules is regulated by specific transport systems on the abluminal and luminal membranes to provide a selective 'transport barrier' and prevent the entry of potentially harmful compounds while facilitating or permitting the entry of required nutrients (including glucose, amino acids, nucleosides and monocarboxylic acids) (38). In addition, members of the ATP-binding cassette (ABC) family, with support of metabolizing enzymes (e.g., cytochrome P450 s), act as efflux transporters by reducing the entry into the brain of numerous toxic components from the diet and environment (39). Unless they can be transferred by specific receptor-mediated transcytosis or by the less specific adsorptive-mediated transcytosis, large hydrophilic molecules such as proteins and peptides are generally excluded $(40,41)$. The two main trafficking routes for BBB transcytosis involve clathrin-coated vesicles and caveolae $(42,43)$. Compared to other tissues, the neutrophil infiltration rate into the brain is low due to the strictly regulated immune cell-BBB interaction. In conditions of increased vascular permeability, circulating neutrophils and mononuclear leukocytes, monocytes and macrophages penetrate into the CNS and have a role complementary to microglia, forming cuffs in the perivascular space, which act as a specific niche for a coordinated immune response $(44,45)$. Failure of the BBB appears to be an important, and possibly a critical event in the development and progression of several brain diseases, including stroke, trauma, epilepsy, neurodegenerative diseases, tumors and bacterial infections. Barrier dysfunction can range from slight and transient tight junction opening, malfunction of transcellular transport mechanisms and ABC transporters to severe and long-lasting barrier breakdown (46). In most cases, it is hard to determine whether barrier dysfunction is the direct cause of disease onset, but it has been established that disturbances in barrier functions contribute to and exacerbate developing pathologies.

The choroid plexus, found in all four ventricles, is comprised mainly of a single layer of highly vascularized epithelial cells connected by tight junctions. Macrophages and leukocytes also occupy the choroid plexus, suggesting its role as a gateway for immune cell trafficking in response to disease and trauma. Cells of the choroid plexus produce the CSF, which is secreted across the epithelium into the ventricles, while the interstitial fluid (ISF), which constitutes the remainder of the brain extracellular fluid, is generated at least in part by secretion across the capillary endothelium of the BBB. The secretion of CSF and ISF is regulated by the $\mathrm{Na}^{+}, \mathrm{K}^{+}$-ATPase, which is expressed in the abluminal side of the BBB endothelium and the apical membrane of the choroid plexus epithelium, and creates the ionic and osmotic gradient that results in flow of water $(47,48)$. The third interface, provided by the arachnoid epithelium, acts as a seal between the extracellular fluids of the CNS and those of the rest of the body (49). Due to its avascular nature and relatively small surface area, the arachnoid does not represent a significant surface for exchange between the blood and the CNS, while it is also regarded as a barrier layer (50).

Pneumococcal trafficking across the barriers. In the pre-antibiotic era, bacterial meningitis was a disease with devastating mortality, which was fatal to virtually all individuals affected (51). However, despite the advent of effective antimicrobial agents, a finite case fatality rate remains, with permanent neurologic sequelae affecting numerous survivors. One potential explanation is that the pathologic consequences of the disease within the CNS progress despite bacterial cure. The pathogen can use two routes to reach the brain, either directly through the endothelium of the BBB or through the choroidal epithelial cells. The BBB is known to be functionally altered in meningitis $(52,53)$, and transit of the bacteria across its endothelium is conceivable via either trans-cellular or para-cellular pathways. Studies investigating the mechanisms of trans-cellular migration showed that the thickness of the bacterial capsule has an important role: While the most opaque variants (thick capsule) were killed, the transparent phase variants (thin capsule) were able to transcytose to the basal surface of the endothelium. This trans-cellular pathway is dependent on the PAF receptor, a choline receptor, and the presence of $\mathrm{CbpA}$ that binds the $\mathrm{pIgR}$ (54). In addition, the pneumococcal surface protein CbpA enables binding to the laminin receptor on the brain endothelium and subsequent trans-endothelial traffic (55). An alternative mechanism involves inter-cellular migration following disruption of tight junctions: A study using a rat model of meningitis showed that pinocytotic vesicle formation appeared to be an early response to pneumococcal infection in the subarachnoid space. This was followed by a progressive increase in complete separation of intercellular junctions as the infection progressed (56), either due to the pneumococcus itself by the release of compounds such as pneumolysin (57) or as result from inflammatory response $(32,58,59)$. However, certain bacterial infections are thought to start in the choroid plexus prior to becoming diffused, suggesting that this may be the predominant site of abnormality in patients suffering from meningitis (60).

\section{Immune response and neuro-inflammatory mechanisms following CNS invasion}

For the normal functioning of the brain, protection from blood-borne toxins, proteins and cells is crucial. Accordingly, 
a compromised BBB is tightly associated with changes in the extracellular milieu of the brain, activation of glial cells and a neuro-inflammatory response which further contributes to the course of a disease (61). In peripheral organs, the presence and nature of pathogens are detected by innate dendritic cells, which then educate lymphocytes about the specifics of pathogen threat detect through the release of selective mediators, and the lymphocytes are then directed to the site harboring the pathogen $(62,63)$. Compared with inflammatory reactions in other tissues, those within the CNS show substantial differences: i) The CNS parenchyma lacks resident dendritic cells and perivascular macrophages, and the vascular pericytes take over the functions of mature dendritic cells (64); ii) astrocytes, microglia and in certain regions mast cells are the innate parenchymal immune cells of the CNS $(65,66)$; iii) due to the presence of the $\mathrm{BBB}$, extravasation of large molecules and blood cells is reduced. Activation of complement cascades and recruitment of cells involved in the adaptive immune response into the CNS parenchyma is therefore more difficult. Under circumstances of successful CNS invasion, pneumococcus replication occurs concurrently with the release of inflammatory bacterial products (67). Consequently, the brain is infiltrated by blood complement system components, antibodies and neutrophils, resulting in bacterial opsonization and phagocytosis (6).

From pathogen recognition to release of inflammatory molecules. Defense begins with the recognition of pathogen-associated molecular patterns (PAMPs), which are structural signatures characteristic of the bacteria. These include bacterial products such as proteins, lipids, nucleic acids and carbohydrates. PAMPs are initially sensed by antigen-presenting cells which express pattern recognition receptors. The main receptors involved in $S$. pneumoniae recognition are Toll-like 2 receptor (TLR-2, also known as CD282), which are recognized by peptidoglycans and lipoteichoic acids (68), TLR-4 (also known as CD284) that are recognized by exotoxin pneumolysin (69) and TLR-9 (also known as CD289), intracellular pattern recognition receptors that are activated by cytosine-guanosine motifs $(\mathrm{CpG})$ in bacterial DNA (70). TLR-2 and -4 bind to myeloid differentiation factor 88 (MyD88) as a common intracellular adapter protein known, which activates the nuclear factor (NF)- $\mathrm{B}$ pathway with subsequent upregulation of pro-inflammatory mediators. Studies have demonstrated that TLR-2 and -4 have a more prominent role than TLR 9 in the induction of the inflammatory response to pathogens and suggested that one receptor may compensate for the absence of the other (71). In addition, family members of the intracellular nucleotide oligomerization domain (NOD) -like receptors (NLRs), Nod-2, also have essential roles in Gram-positive peptidoglycan detection: When activated, they stimulate NF- $\kappa \mathrm{B}$ or mitogen-activated protein kinase pathways and activate caspase-1 (72). This in turn stimulates the production of inflammatory cytokines and chemokines by astrocytes and microglia that express TLRs and NLRs (73). In humans, certain deficiencies and polymorphisms such as phosphorylation of interleukin receptor-associated kinase and Myd88 adapter protein have been associated with invasive pneumococcal disease such as meningitis (74).

\section{Immune residents of the brain-microglia and astrocytes}

Microglia. As described by Del Rio Hortega, microglia comprise up to $20 \%$ of the non-neuronal cell population, are derived from the mesoderm and are considered as the resident macrophages of the CNS (75). The brain of adults has two major subsets of microglia: Parenchymal and perivascular microglia. The latter are located in the basal lamina of brain capillaries and the choroid plexus. The phagocytic properties of microglia (76) have been considered to be the first line of defense in the CNS and to impact numerous immune responses of the brain against infectious and acute as well as chronic neurological diseases $(66,77)$. Resting microglia have small bodies and long, thin processes with ramified morphology, which correspond to the vigilant form which is able to promptly recognize homeostatic disturbances in the CNS (77). Under pathological conditions, microglia become activated and are characterized by an amoeboid morphology with short processes. Surface antigens and cytokine release corresponding to distinct phenotypes are associated with the transition from one form to another (78). The activated, phagocytic phenotype has been indicated to mediate the elimination of neurotoxic substances from brain parenchyma, such as blood-borne albumin (79). Since microglial cells are located in the perivascular space, it is likely that their interactions with endothelial cells influence the properties of the BBB. It has been suggested that, similarly to astrocytes, activation of microglia restores BBB integrity after its chemically stimulated loss by directing tight junction proteins to para-cellular domains (80). However, in neuro-inflammation, activated microglia may cause barrier impairment and BBB dysfunction by releasing the pro-inflammatory cytokine TNF- $\alpha$ (81). Apart from their participation in inflammatory and infectious events and their scavenger function, microglia also take part in several important physiological events in the adult brain, including induction of apoptosis in specific subpopulations of developing neurons, control of synaptogenesis and synaptic transmission as well as synthesis of neurotrophic factors (82).

Astrocytes. Glial astrocytic cells are ideally situated to function as mediators in neurovascular communication; they surround synapses and can thus sense neuronal activity, whereas their end-foot processes envelop blood vessels and may signal (and sense) smooth muscle cells and/or pericytes (83). Astrocytes are enriched in potassium channels, purinergic receptors and the gap junction protein connexin 43, as well as the water-channel protein aquaporin-4 (84), indicating key roles in potassium buffering (85), calcium-dependent glio-vascular signaling and regulation of brain water content. Astrocytes release several vasoactive factors, including nitric oxide (NO) and arachidonic acid metabolites, having a prominent role as mediators of vasomotor activity (86). Moreover, astrocytes produce neutrophins and a wide range of anti-inflammatory cytokines (87). Upon activation of various signaling pathways [e.g. TLR/NLR and transforming growth factor (TGF) beta], astrocytes participate in innate immune reactions, synthesize and release neuro-inflammatory mediators, including several complement components, cytokines such as IL-1 $\beta$ and IL-6, and chemokines (88-92). 
Inflammatory mediators. Following recognition of the pathogen and activation of non-neuronal cells, microglia and astrocytes produce and release a wide range of inflammatory molecules in the brain. These include molecules such as cytokines, free radicals, matrix metalloproteinases (MMPs) and chemokines, which contribute to an increase in $\mathrm{BBB}$ permeability and enable recruitment of leukocytes to the site of infection. Alongside bacterial elimination, this results with brain edema, increased intracranial pressure and impaired cerebral blood flow, and may lead to irreversible neuronal injury (88).

Cytokines. Cytokines are multifunctional pleiotropic proteins with crucial roles in cellular activation and cell-to-cell communication. Depending on their function, they are classified as being either pro- or anti-inflammatory according to the final balance of their effects on the immune system. Cytokines not only participate in the immune response but also in a variety of physiological and pathological processes, including events in the periphery and CNS; therefore, they act as immune regulators as well as neuromodulators. The neuro-immune interactions are bidirectional-cytokines can modulate the action, differentiation and survival of neurons, while neurotransmitters and neuropeptides released from neurons have a central role in influencing the immune response. The various cytokines directly affecting the CNS either originate from the peripheral immune system, in which case they migrate across the opened $\mathrm{BBB}$, or they are produced locally within the CNS by brain resident cells (89).

Following pneumococcal infection, release of pro-inflammatory cytokines includes molecules such as IL-1, IL-6, TNF- $\alpha$ and interferon (IFN) $-\gamma$. These cytokines are released by endothelial cells, astrocytes, microglia and neurons, resulting in increased $\mathrm{BBB}$ permeability and recruitment of leukocytes from the circulatory blood $(32,90)$. TNF- $\alpha$ is a 158 amino acid cytokine; it was found to be produced in the cortex and hippocampus during the first $6 \mathrm{~h}$, and remained elevated until $96 \mathrm{~h}$ after meningitis initiation $(91,92)$. TNF- $\alpha$ binding to its cognate receptor leads to $\mathrm{NF}-\kappa \mathrm{B}$ activation that regulates the expression of other pro-inflammatory mediators (93). In patients with bacterial meningitis, intrathecal levels of TNF- $\alpha$ were correlated with the severity of BBB disruption, neurologic sequelae and disease severity (58). However, TNF- $\alpha$ deficient mice infected with $S$. pneumoniae demonstrated increased mortality and spatial memory deficits (94), suggesting that TNF- $\alpha$ reflects disease severity but is not required to induce neurological complications. IL-1 $\beta$ is a pro-inflammatory cytokine produced early after bacterial invasion of the brain in the cortex and hippocampus by perivascular mononuclear phagocytes, macrophages and glial cells through stimulation of bacterial compounds or TNF- $\alpha(91,92)$. IL-1 $\beta$ increases the expression of nearly all other cytokines, including TNF- $\alpha$, IL-6, IFN- $\gamma$ and chemokines; however, its role in bacterial meningitis remains elusive. In patients with bacterial meningitis, IL-1 $\beta$ levels were not correlated with the degree of BBB opening (58). By contrast, decreased levels of IL-1 $\beta$ were associated with lower intracranial pressure (ICP), leukocyte recruitment and brain edema (95). Intrathecal administration of IL-1 $\beta$ did not lead to CSF pleocytosis or brain edema, but administration of anti-IL-1 $\beta$ antibodies decreased TNF- $\alpha$-induced leukocyte influx (96). IL-1 receptor (IL-1R) gene-deficient mice succumbed earlier to the disease and their mortality rate was significantly elevated, indicating that endogenous IL-1 $\beta$ is required for an adequate host defense in pneumococcal meningitis (97). IL-6 is expressed mostly in the cortex and is produced by endothelial cells, astrocytes and monocytes (98). Although the effects of IL-6 are predominantly pro-inflammatory, including leukocyte recruitment, the potent induction of acute-phase proteins and fever (99), it also acts as an anti-inflammatory cytokine. Indeed, IL-6 gene deficiency in mice with bacterial meningitis was found to be associated with an increased inflammatory response and an impaired defense against pneumococcal pneumonia, as well as reduced vascular permeability and ICP $(100,101)$. IFN is another important pro-inflammatory mediator in pneumococcal meningitis, found at elevated concentrations in meningitis patients' CSF (102). It has been suggested that IFN- $\gamma$ is produced following bacterial recognition through activation of the NLR inflammasome pathways $(103,104)$.

Anti-inflammatory cytokines such as IL-10 and TGF- $\beta$ have been shown to be upregulated during pneumococcal meningitis. IL-10 is a potent immune-suppressive cytokine produced by brain cells such as neurons and microglia as well as macrophages and monocytes (105), and elevated levels have been found in the CSF of patients with bacterial meningitis (106). IL-10 was shown to inhibit the production of pro-inflammatory cytokines including TNF- $\alpha$ and IL-6, as well as the release of reactive oxygen species (ROS) (107), and to induce impairment of neutrophil phagocytosis and killing (108). Accordingly, systemic administration of recombinant IL-10 in a rat model of pneumococcal meningitis resulted in lower levels of pro-inflammatory cytokines, CSF pleocytosis and cerebral edema (107). However, in IL-10 knockout mice with pneumococcal meningitis, bacterial loads and survival rates were similar to those in wild-type mice (97). TGF- $\beta$ is a pleiotropic cytokine with potent inflammatory regulatory activity expressed in neurons and glial cells. Among its multiple functions, it modulates T-cell activity, including proliferation and differentiation processes $(109,110)$. The influence of TGF- $\beta$ on the immune reactivity of the CNS following infection remains to be under debate; it suppresses the production of pro-inflammatory cytokines IL-1 $\beta$, IL- 6 and TNF- $\alpha$ from microglia and macrophages $(111,112)$, but has also been reported to increase the production in cultured astrocytes (113). Absence of TGF- $\beta$ signaling was demonstrated to facilitate the recruitment of leukocytes and the clearance of S. pneumoniae in the CNS of mice with meningitis, resulting in reduced cerebrovascular complications (114).

Chemokines. Chemokines are a subgroup of cytokines, which are considered to have chemotactic activity due to their ability to induce directed chemotaxis in nearby responsive cells. In pneumococcal meningitis, multiple chemokines have been reported to be upregulated and enhance the recruitment and accumulation of inflammatory cells in the CSF (115). IL-8 is produced by a wide range of cells, including macrophages and monocytes, through IL- $1 \beta$, TNF- $\alpha$ and stimuli of live bacteria. In rabbits with pneumococcal meningitis, intravenous administration of a monoclonal antibody to IL-8 attenuated pleocytosis (116). Another group of chemokines are the CC 
chemokine ligands (117), including monocyte chemoattractant proteins and macrophage inflammatory proteins (MIPs), which are released by astrocytes and microglia $(118,119)$. Intracisternal administration of recombinant molecules was found to induce BBB dysfunction, CSF leukocytosis and brain edema (96).

Leukocyte migration. As part of the immune response to bacterial infection, blood-derived leukocytes, such as neutrophilic granulocytes and monocytes, enter the CNS to clear the pathogen. The recruitment of leukocytes through the BBB is associated with meningeal and perivascular macrophage activation and upregulation of the endothelial adhesion molecules selectin and integrin $(120,121)$. The PAF is a protein which facilitates the adhesion of leukocytes to the endothelium and is produced by neutrophils and endothelial cells in response to inflammatory stimulation (122). Another translocation mediator in pneumococcal meningitis is the urokinase-type plasminogen activator, which is also considered as a fibrin degrader (123). However, after migration into the CNS, leukocytes release a variety of toxic molecules (e.g., ROS), causing cerebrovascular complications and neuronal injury (115).

MMPs. MMPs are a family of neutral proteases which are of importance in normal development, wound healing and a large variety of pathological processes, including neuro-inflammation and the spread of metastatic cancer cells (124). In the CNS, MMPs have been shown to degrade components of the basal lamina, leading to BBB breakdown, and contribute to inflammation in numerous neurological diseases. In response to cellular stress, MMPs are secreted by a wide range of cells, including activated neutrophils and macrophages, neurons and glial cells (125). High concentrations of MMP-8 and -9 have been detected in the CSF of patients with bacterial meningitis, and indeed, high concentrations of MMP-9 have been demonstrated to be correlated with TNF- $\alpha$ levels, to induce BBB dysfunction, and to be a risk factor for the development of post-meningitis neurological deficits (125).

Free radicals. A plethora of studies on patients as well as animal models implied that free radicals, including ROS and reactive nitrogen species (RNS), hydrogen peroxide $\left(\mathrm{H}_{2} \mathrm{O}_{2}\right)$ and hydroxyl peroxide have a central role in the development of intracranial complications and brain damage in bacterial meningitis $(126,127)$. Brain cells and attracted leukocytes produce free radicals as part of the host immune response to invasive bacterial infection $(128,129)$. S. pneumoniae itself is also an important source of $\mathrm{H}_{2} \mathrm{O}_{2}$, which causes direct cytotoxic damage and also reacts with the host's NO to form peroxynitrite $\left(\mathrm{ONOO}^{-}\right)$, a highly reactive oxidant (130). $\mathrm{ONOO}^{-}$is formed at sites where $\mathrm{NO}$ and superoxide anions are produced simultaneously $(131,132)$. ONOO- can be cytotoxic by a number of mechanisms, including tyrosine nitration that affects cellular signaling (133), lipid peroxidation that induces loss of membrane function and integrity (134), and production of cytokines and MMPs $(135,136)$. Adjuvant therapy with an $\mathrm{ONOO}^{-}$scavenger reduces the number of CSF leukocytes as well as IL-1 $\beta$ and MIP-2 concentrations in the brain (137), which suggests that ROS/RNS and pro-inflammatory chemokines/cytokines are involved in the attraction of blood-bound leukocytes into the subarachnoid space (138). Furthermore, treatment with antioxidants was shown to attenuate BBB leakage $(137,139)$.

\section{Brain injury following pneumococcal invasion}

In spite of advances in antimicrobial therapies and supportive care, brain injury and mortality associated with and resulting from $S$. pneumoniae infection have remained significant.

Cellular damage. An important histopathological finding in patients with $S$. pneumoniae meningitis as well as in experimental meningitis is cell death in the dentate gyrus of the hippocampus (140), which was also correlated with the development of learning deficits $(141,142)$. S. pneumoniae is able to induce two functionally distinct forms of programmed cell death in the brain, which proceed either via TLR-dependent or -independent pathways. The pneumococcal cell wall is a pro-inflammatory component and causes apoptosis in the hippocampus mediated via TLR-2 and activation of caspases (143). Living pneumococci and the major cytotoxins pneumolysin and $\mathrm{H}_{2} \mathrm{O}_{2}$ appear to induce damage to endothelial cells of the BBB through a TLR-independent pathway (143). The these toxins induce an increase in ROS and intracellular calcium, resulting in mitochondrial dysfunction that leads to the release of apoptosis-inducing factors into the cytosol $(130,144)$.

Cerebrovascular injury. Pneumococcal meningitis is at times accompanied by cerebrovascular complications, including ischemic stroke, venous thrombosis, intracerebral hemorrhage and vasculitis (145-148). Additional studies have suggested that vasospasm, thrombosis and diffused cerebral intravascular coagulation may each contribute to cerebral injury (149-151). Other factors, including alterations in blood pressure and impaired cerebral auto-regulation of blood flow may also have a role $(152,153)$. Following bacterial infection and stroke, cells in the penumbra are subjected to various inflammatory components such as infiltrating leukocytes, pro-inflammatory cytokines and free radicals, which may be deleterious and lead to further cellular damage (154). Furthermore, subcortical ischemic white matter lesions have been identified, which led to axonal injury (155). Recently, the pro-inflammatory cytokine IL-1 was identified as a key mediator of pneumococcal infection-induced cerebral ischemia and neuronal injury (156). In a model of ischemic stroke, bacterial aspiration led to severe pneumonia, which persisted for fourteen days after stroke induction, suggesting that stroke increases the susceptibility to infection (157). Another severe vascular complication in pneumococcal meningitis is venous thrombosis $(158,159)$, associated with impairments of blood flow and perfusion pressure, intracranial hemorrhage, BBB dysfunction and cerebral edema $(160,161)$.

Seizures. Seizures are a common complication of S. pneumoniae meningitis during the acute phase of illness, with an increased risk of developing unprovoked seizures (e.g., epilepsy) later in life $(162,163)$. Seizures occur frequently in adult patients and are associated with severe inflammation and structural CNS lesions $(164,165)$. In children, the probability 
of the occurrence of status epilepticus associated with fever is higher than that of short febrile seizures, and the classical symptoms and signs of meningitis may be absent under such conditions $(166,167)$.

Studies have suggested that cerebrovascular injury and BBB dysfunction, which allow the infiltration of albumin, lead to activation of TGF- $\beta$ signaling in astrocytes. This further results in a neuro-inflammatory response associated with up-regulation and release of IL- $1 \beta$, IL- 6 and TGF- $\beta$ cytokines and seizures (168-172). Thus, in patients with pneumococcal meningitis, increased BBB permeability and inflammatory response as described above may similarly increase the likelihood of seizures.

Labyrinthitis. One of the most common sequelae of pneumococcal meningitis is bacterial labyrinthitis and sensory neural hearing loss. Labyrinthitis occurs as the bacteria reach the cochlear aqueduct from the subarachnoid space or travel with the eighth cranial nerve in the internal auditory canal $(173,174)$, contributing to hair cell injury and neuronal cell death (175). A study using a mouse model of pneumococcal meningitis suggested a pro-inflammatory role for the TLR-MyD88 signaling pathway as a trigger for labyrinthitis (176). Synthesis of TNF- $\alpha$ and free radicals has been demonstrated to have an important role in hearing loss following infection, and inhibition of their production was found to have a protective effect $(175,177)$.

Neuropsychological and mental-status impairment. Mild to severe intellectual and behavioral deficits, including cognitive impairment, learning disabilities and attention deficit hyperactivity disorder are well-recognized complications of bacterial meningitis in children and are the most common long-term sequelae $(178,179)$. Psychiatric illness and neurodegenerative diseases have been linked with cerebrovascular damage and BBB alterations: An elevated $\mathrm{CSF} /$ serum albumin ratio in patients suffering from dementia compared to non-demented individuals was found (180), and elevated serum levels of S100 calcium-binding protein B, normally found exclusively in the brain, were demonstrated in patients suffering from depression and schizophrenia (181). In addition, accumulating evidence indicated that immunologic responses have a role in deficits in cognitive function as well as depression; Increases in pro-inflammatory cytokines, including TNF- $\alpha$, IFN and IL-1 $\beta$ and -6 , alongside a relative reduction of the anti-inflammatory cytokine IL-10, were demonstrated in depression. Furthermore, a positive correlation was shown between plasma concentrations of inflammatory mediators, such as IL-1 $\beta$ and IL-6, and the severity of depression symptoms $(182,183)$. These suggest that early vascular injury during meningitis, including BBB dysfunction and neuroinflammatory processes, can be associated with delayed neuropsychological and mental problems.

\section{Summary}

In spite of the wealth of data accumulated on pneumococcal meningitis, as well as the existence of antibiotics, vaccination protocols and adjuvant treatments (e.g., drugs targeting free radicals, the caspase cascade and inflammatory mediators), CNS invasion by $S$. pneumonia results in severe neuropathologies. Several studies point to a direct contribution of BBB dysfunction and inflammatory signaling to the etiology of brain diseases, including those caused by bacterial infection. Thus, following diagnosis of peripheral infection with S. pneumonia, imaging of cerebrovascular permeability and measurement of neuro-inflammatory mediators in blood and CSF may aid in identifying patients that are at higher risk of contracting meningitis. Furthermore, since bacterial infection of the CNS requires crossing through the dysfunctional endothelium of BBB and the epithelium of the choroid plexus, cerebral vessels may serve as a potential target for preventing and treating bacterial meningitis.

\section{Acknowledgements}

The present study was supported by the Israel Ministry of Health (grant nos. 4476, 5540 and 3000003867 to YMN), BG Negev Technologies, Ben-Gurion University of the Negev (grant no. 80904101 to YMN), the Center of Emerging Diseases, Tropical Diseases \& Aids (grant no. 2506 to YMN; Beer Sheva, Israel) and the Israel Academy of Science (grant no. $613 / 04$ to YMN).

\section{References}

1. VanDemark M: Acute bacterial meningitis: Current review and treatment update. Crit Care Nurs Clin North Am 25: 351-361, 2013.

2. Lynch JP III and Zhanel GG: Streptococcus pneumoniae: Epidemiology and risk factors, evolution of antimicrobial resistance, and impact of vaccines. Curr Opin Pulm Med 16: $217-225,2010$

3. Schmidt H, Heimann B, Djukic M, Mazurek C, Fels C, Wallesch CW and Nau R: Neuropsychological sequelae of bacterial and viral meningitis. Brain 129: 333-345, 2006.

4. van de Beek D, Schmand B, de Gans J, Weisfelt M, Vaessen H, Dankert J and Vermeulen M: Cognitive impairment in adults with good recovery after bacterial meningitis. J Infect Dis 186: 1047-1052, 2002.

5. Hicks LA, Harrison LH, Flannery B, Hadler JL, Schaffner W, Craig AS, Jackson D, Thomas A, Beall B, Lynfield R, et al: Incidence of pneumococcal disease due to non-pneumococcal conjugate vaccine (PCV7) serotypes in the United States during the era of widespread PCV7 vaccination, 1998-2004. J Infect Dis 196: 1346-1354, 2007.

6. Mook-Kanamori BB, Geldhoff M, van der Poll T and van de Beek D: Pathogenesis and pathophysiology of pneumococcal meningitis. Clin Microbiol Rev 24: 557-591, 2011.

7. Brugger SD, Hathaway LJ and Mühlemann K: Detection of Streptococcus pneumoniae strain cocolonization in the nasopharynx. J Clin Microbiol 47: 1750-1766, 2009.

8. Aas JA, Paster BJ, Stokes LN, Olsen I and Dewhirst FE: Defining the normal bacterial flora of the oral cavity. J Clin Microbiol 43: 5721-5732, 2005.

9. Moschioni M, Donati C, Muzzi A, Masignani V, Censini S, Hanage WP, Bishop CJ, Reis JN, Normark S Henriques-Normark $\mathrm{B}$, et al: Streptococcus pneumoniae contains 3 rlrA pilus variants that are clonally related. J Infect Dis 197: 888-896, 2008.

10. Bagnoli F, Moschioni M, Donati C, Dimitrovska V, Ferlenghi I, Facciotti C, Muzzi A, Giusti F, Emolo C, Sinisi A, et al: A second pilus type in Streptococcus pneumoniae is prevalent in emerging serotypes and mediates adhesion to host cells. J Bacteriol 190: 5480-5492, 2008

11. Burnaugh AM, Frantz LJ and King SJ: Growth of Streptococcus pneumoniae on human glycoconjugates is dependent upon the sequential activity of bacterial exoglycosidases. J Bacteriol 190: 221-230, 2008.

12. Feldman C, Mitchell TJ, Andrew PW, Boulnois GJ, Read RC, Todd HC, Cole PJ and Wilson R: The effect of Streptococcus pneumoniae pneumolysin on human respiratory epithelium in vitro. Microb Pathog 9: 275-284, 1990. 
13. Davis KM, Akinbi HT, Standish AJ and Weiser JN: Resistance to mucosal lysozyme compensates for the fitness deficit of peptidoglycan modifications by Streptococcus pneumoniae. PLoS Pathog 4: e1000241, 2008

14. Weiser JN, Bae D, Fasching C, Scamurra RW, Ratner AJ and Janoff EN: Antibody-enhanced pneumococcal adherence requires IgA1 protease. Proc Natl Acad Sci USA 100: 4215-4220, 2003.

15. Shaper M, Hollingshead SK, Benjamin WH Jr and Briles DE: PspA protects Streptococcus pneumoniae from killing by apolactoferrin, and antibody to PspA enhances killing of pneumococci by apolactoferrin [corrected]. Infect Immun 72: 5031-5040, 2004.

16. Bogaert D, Thompson CM, Trzcinski K, Malley R and Lipsitch M: The role of complement in innate and adaptive immunity to pneumococcal colonization and sepsis in a murine model. Vaccine 28: 681-685, 2010.

17. Hammerschmidt S, Wolff S, Hocke A, Rosseau S, Müller E and Rohde M: Illustration of pneumococcal polysaccharide capsule during adherence and invasion of epithelial cells. Infect Immun 73: 4653-4667, 2005.

18. Ogunniyi AD, Mahdi LK, Jennings MP, McEwan AG, McDevitt CA, Van der Hoek MB, Bagley CJ, Hoffmann P, Gould KA and Paton JC: Central role of manganese in regulation of stress responses, physiology, and metabolism in Streptococcus pneumoniae. J Bacteriol 192: 4489-4497, 2010.

19. Anderton JM, Rajam G, Romero-Steiner S, Summer S, Kowalczyk AP, Carlone GM, Sampson JS and Ades EW: E-cadherin is a receptor for the common protein pneumococcal surface adhesin A (PsaA) of Streptococcus pneumoniae. Microb Pathog 42: 225-236, 2007.

20. Pracht D, Elm C, Gerber J, Bergmann S, Rohde M, Seiler M Kim KS, Jenkinson HF, Nau R and Hammerschmidt S: PavA of Streptococcus pneumoniae modulates adherence, invasion, and meningeal inflammation. Infect Immun 73: 2680-2689, 2005.

21. Hammerschmidt S, Talay SR, Brandtzaeg P and Chhatwal GS SpsA, a novel pneumococcal surface protein with specific binding to secretory immunoglobulin A and secretory component. Mol Microbiol 25: 1113-1124, 1997.

22. Ling E, Feldman G, Portnoi M, Dagan R, Overweg K, Mulholland F, Chalifa-Caspi V, Wells J and Mizrachi-Nebenzahl Y: Glycolytic enzymes associated with the cell surface of Streptococcus pneumoniae are antigenic in humans and elicit protective immune responses in the mouse. Clin Exp Immunol 138: 290-298, 2004

23. Blau K, Portnoi M, Shagan M, Kaganovich A, Rom S, Kafka D, Chalifa Caspi V, Porgador A, Givon-Lavi N, Gershoni JM, et al Flamingo cadherin: A putative host receptor for Streptococcus pneumoniae. J Infect Dis 195: 1828-1837, 2007.

24. Muchnik L, Adawi A, Ohayon A, Dotan S, Malka I, Azriel S, Shagan M, Portnoi M, Kafka D, Nahmani H, et al: NADH oxidase functions as an adhesin in Streptococcus pneumoniae and elicits a protective immune response in mice. PLoS One 8 : e61128, 2013.

25. Binsker U, Kohler TP, Krauel K, Kohler S, Schwertz H and Hammerschmidt S: Pneumococcal adhesins PavB and PspC are important for the interplay with human thrombospondin-1. J Biol Chem 290: 14542-14555, 2015.

26. Rosenow C, Ryan P, Weiser JN, Johnson S, Fontan P, Ortqvist A and Masure HR: Contribution of novel choline-binding proteins to adherence, colonization and immunogenicity of Streptococcus pneumoniae. Mol Microbiol 25: 819-829, 1997.

27. Zhang JR, Mostov KE, Lamm ME, Nanno M, Shimida S, Ohwaki M and Tuomanen E: The polymeric immunoglobulin receptor translocates pneumococci across human nasopharyngeal epithelial cells. Cell 102: 827-837, 2000.

28. Kadioglu A, Weiser JN, Paton JC and Andrew PW: The role of Streptococcus pneumoniae virulence factors in host respiratory colonization and disease. Nat Rev Microbiol 6: 288-301, 2008.

29. Abeyta M, Hardy GG and Yother J: Genetic alteration of capsule type but not PspA type affects accessibility of surface-bound complement and surface antigens of Streptococcus pneumoniae. Infect Immun 71: 218-225, 2003.

30. Li J, Glover DT, Szalai AJ, Hollingshead SK and Briles DE: PspA and PspC minimize immune adherence and transfer of pneumococci from erythrocytes to macrophages through their effects on complement activation. Infect Immun 75: 5877-5885, 2007.

31. Jarva H, Jokiranta TS, Würzner R and Meri S: Complement resistance mechanisms of streptococci. Mol Immunol 40: 95-107, 2003
32. Fassbender K, Schminke U, Ries S, Ragoschke A, Kischka U, Fatar M and Hennerici M: Endothelial-derived adhesion molecules in bacterial meningitis: Association to cytokine release and intrathecal leukocyte-recruitment. J Neuroimmunol 74: 130-134, 1997.

33. Levi M and van der Poll T: Inflammation and coagulation. Crit Care Med 38 (2 Suppl): S26-S34, 2010.

34. Østerud B: Tissue factor expression in blood cells. Thromb Res 125 (Supp 1): S31-S34, 2010.

35. Schoknecht K, Prager O, Vazana U, Kamintsky L, Harhausen D, Zille M, Figge L, Chassidim Y, Schellenberger E, Kovács R, et al: Monitoring stroke progression: In vivo imaging of cortical perfusion, blood-brain barrier permeability and cellular damage in the rat photothrombosis model. J Cereb Blood Flow Metab 34: 1791-1801, 2014.

36. Abbott NJ, Patabendige AA, Dolman DE, Yusof SR and Begley DJ: Structure and function of the blood-brain barrier. Neurobiol Dis 37: 13-25, 2010.

37. Goldman E: Vitalfarbung am zentralnervensystem; Beitrag zur Physio-Pathologie des Plexus chorioideus und der Hirnhäute. Abhandl Konigl Preuss Akad Wiss 1: 1-60, 1913.

38. Ohtsuki S and Terasaki T: Contribution of carrier-mediated transport systems to the blood-brain barrier as a supporting and protecting interface for the brain; importance for CNS drug discovery and development. Pharm Res 24: 1745-1758, 2007.

39. Dutheil F, Jacob A, Dauchy S, Beaune P, Scherrmann JM, Declèves X and Loriot MA: ABC transporters and cytochromes P450 in the human central nervous system: Influence on brain pharmacokinetics and contribution to neurodegenerative disorders. Expert Opin Drug Metab Toxicol 6: 1161-1174, 2010.

40. Pardridge WM: Molecular biology of the blood-brain barrier. Methods Mol Med 89: 385-399, 2003.

41. Hervé F, Ghinea N and Scherrmann JM: CNS delivery via adsorptive transcytosis. AAPS J 10: 455-72, 2008.

42. Mayor S and Pagano RE: Pathways of clathrin-independent endocytosis. Nat Rev Mol Cell Biol 8: 603-612, 2007.

43. Vercauteren D, Vandenbroucke RE, Jones AT, Rejman J, Demeester J, De Smedt SC, Sanders NN and Braeckmans K: The use of inhibitors to study endocytic pathways of gene carriers: Optimization and pitfalls. Mol Ther 18: 561-569, 2010.

44. Bechmann I, Priller J, Kovac A, Böntert M, Wehner T, Klett FF, Bohsung J, Stuschke M, Dirnagl U and Nitsch R: Immune surveillance of mouse brain perivascular spaces by blood-borne macrophages. Eur J Neurosci 14: 1651-1658, 2001.

45. Konsman JP, Drukarch B and Van Dam AM: (Peri)vascular production and action of pro-inflammatory cytokines in brain pathology. Clin Sci (Lond) 112: 1-25, 2007.

46. Förster C: Tight junctions and the modulation of barrier function in disease. Histochem Cell Biol 130: 55-70, 2008.

47. Abbott NJ: Evidence for bulk flow of brain interstitial fluid: Significance for physiology and pathology. Neurochem Int 45: 545-552, 2004.

48. Dragunow M: Meningeal and choroid plexus cells-Novel drug targets for CNS disorders. Brain Res 1501: 32-55, 2013.

49. Abbott NJ, Rönnbäck L and Hansson E: Astrocyte-endothelial interactions at the blood-brain barrier. Nat Rev Neurosci 7: $41-53,2006$

50. Kandel ER, Schwartz JH and Jessel TM: Principles of Neural Science. 4th ed. New York: McGraw-Hill, 2000.

51. Swartz MN: Bacterial meningitis: More involved than just the meninges. N Engl J Med 311: 912-914, 1984.

52. Prockop LD and Fishman RA: Experimental pneumococcal meningitis. Permeability changes influencing the concentration of sugars and macromolecules in cerebrospinal fluid. Arch Neurol 19: 449-463, 1968

53. Cooper AJ, Beaty HN, Oppenheimer SI, Goodner CJ and Petersdorf RG: Studies on the pathogenesis of meningitis. VII. Glucose transport and spinal fluid production in experimental pneumococcal meningitis. J Lab Clin Med 71: 473-483, 1968.

54. Ring A, Weiser JN and Tuomanen EI: Pneumococcal trafficking across the blood-brain barrier. Molecular analysis of a novel bidirectional pathway. J Clin Invest 102: 347-360, 1998.

55. Orihuela CJ, Mahdavi J, Thornton J, Mann B, Wooldridge KG, Abouseada N, Oldfield NJ, Self T, Ala'Aldeen DA and Tuomanen EI: Laminin receptor initiates bacterial contact with the blood brain barrier in experimental meningitis models. J Clin Invest 119: 1638-1646, 2009.

56. Quagliarello VJ, Long WJ and Scheld WM: Morphologic alterations of the blood-brain barrier with experimental meningitis in the rat. Temporal sequence and role of encapsulation. J Clin Invest 77: 1084-1095, 1986. 
57. Zysk G, Schneider-Wald BK, Hwang JH, Bejo L, Kim KS, Mitchell TJ, Hakenbeck R and Heinz HP: Pneumolysin is the main inducer of cytotoxicity to brain microvascular endothelial cells caused by Streptococcus pneumoniae. Infect Immun 69: 845-852, 2001 .

58. Sharief MK, Ciardi M and Thompson EJ: Blood-brain barrier damage in patients with bacterial meningitis: Association with tumor necrosis factor-alpha but not interleukin-1 beta. J Infect Dis 166: 350-358, 1992.

59. Freyer D, Manz R, Ziegenhorn A, Weih M, Angstwurm K, Döcke WD, Meisel A, Schumann RR, Schönfelder G, Dirnagl U and Weber JR: Cerebral endothelial cells release TNF-alpha after stimulation with cell walls of Streptococcus pneumoniae and regulate inducible nitric oxide synthase and ICAM-1 expression via autocrine loops. J Immunol 163: 4308-4314, 1999.

60. Mathews VP and Smith RR: Choroid plexus infections: Neuroimaging appearances of four cases. AJNR Am J Neuroradiol 13 374-378, 1992.

61. Kim SY, Buckwalter M, Soreq H, Vezzani A and Kaufer D: Blood-brain barrier dysfunction-induced inflammatory signaling in brain pathology and epileptogenesis. Epilepsia 53 (Suppl 6): 37-44, 2012.

62. Dudda JC, Lembo A, Bachtanian E, Huehn J, Siewert C, Hamann A, Kremmer E, Förster R and Martin SF: Dendritic cells govern induction and reprogramming of polarized tissue-selective homing receptor patterns of T cells: Important roles for soluble factors and tissue microenvironments. Eur J Immunol 35: 1056-1065, 2005.

63. Oyoshi MK, Elkhal A, Scott JE, Wurbel MA, Hornick JL, Campbell JJ and Geha RS: Epicutaneous challenge of orally immunized mice redirects antigen-specific gut-homing $\mathrm{T}$ cells to the skin. J Clin Invest 121: 2210-2220, 2011.

64. Xanthos DN and Sandkühler J: Neurogenic neuroinflammation: Inflammatory CNS reactions in response to neuronal activity. Nat Rev Neurosci 15: 43-53, 2014.

65. Skaper SD, Giusti P and Facci L: Microglia and mast cells: Two tracks on the road to neuroinflammation. FASEB J 26 3103-3117, 2012.

66. Kettenmann H, Hanisch UK, Noda M and Verkhratsky A Physiology of microglia. Physiol Rev 91: 461-553, 2011.

67. Sellner J, Täuber MG and Leib SL: Pathogenesis and pathophysiology of bacterial CNS infections. Handb Clin Neurol 96 $1-16,2010$

68. Schröder NW, Morath S, Alexander C, Hamann L, Hartung T, Zähringer U, Göbel UB, Weber JR and Schumann RR: Lipoteichoic acid (LTA) of Streptococcus pneumoniae and Staphylococcus aureus activates immune cells via Toll-like receptor (TLR)-2, lipopolysaccharide-binding protein (LBP), and CD14, whereas TLR-4 and MD-2 are not involved. J Biol Chem 278: 15587-15594, 2003.

69. Malley R, Henneke P, Morse SC, Cieslewicz MJ, Lipsitch M, Thompson CM, Kurt-Jones E, Paton JC, Wessels MR and Golenbock DT: Recognition of pneumolysin by Toll-like receptor 4 confers resistance to pneumococcal infection. Proc Natl Acad Sci USA 100: 1966-1971, 2003.

70. Hemmi H, Takeuchi O, Kawai T, Kaisho T, Sato S, Sanjo H, Matsumoto M, Hoshino K, Wagner H, Takeda K and Akira S A Toll-like receptor recognizes bacterial DNA. Nature 408: 740-745, 2000.

71. Klein M, Obermaier B, Angele B, Pfister HW, Wagner H, Koedel U and Kirschning CJ: Innate immunity to pneumococcal infection of the central nervous system depends on toll-like receptor (TLR) 2 and TLR4. J Infect Dis 198: 1028-1036, 2008.

72. Opitz B, Eitel J, Meixenberger K and Suttorp N: Role of Toll-like receptors, NOD-like receptors and RIG-I-like receptors in endothelial cells and systemic infections. Thromb Haemost 102: 1103-1109, 2009.

73. Blamire AM, Anthony DC, Rajagopalan B, Sibson NR, Perry VH and Styles P: Interleukin-1beta -induced changes in blood-brain barrier permeability, apparent diffusion coefficient, and cerebral blood volume in the rat brain: A magnetic resonance study. J Neurosci 20: 8153-8159, 2000.

74. Picard C, von Bernuth H, Ghandil P, Chrabieh M, Levy O, Arkwright PD, McDonald D, Geha RS, Takada H, Krause JC, et al: Clinical features and outcome of patients with IRAK-4 and MyD88 deficiency. Medicine (Baltimore) 89: 403-425, 2010.

75. Pérez-Cerdá F, Sánchez-Gómez MV and Matute C: Pío del Río Hortega and the discovery of the oligodendrocytes. Front Neuroanat 9: 92, 2015
76. Fu R, Shen Q, Xu P, Luo JJ and Tang Y: Phagocytosis of Microglia in the central nervous system diseases. Mol Neurobiol 49: 1422-1434, 2014.

77. Kreutzberg GW: Microglia: A sensor for pathological events in the CNS. Trends Neurosci 19: 312-328, 1996.

78. Kim SU and de Vellis J: Microglia in health and disease. J Neurosci Res 81: 302-313, 2005

79. Alonso A, Reinz E, Fatar M, Hennerici MG and Meairs S: Clearance of albumin following ultrasound-induced blood-brain barrier opening is mediated by glial but not neuronal cells Brain Res 1411: 9-16, 2011.

80. Willis CL: Glia-induced reversible disruption of blood-brain barrier integrity and neuropathological response of the neurovascular unit. Toxicol Pathol 39: 172-185, 2011.

81. Nishioku T, Matsumoto J, Dohgu S, Sumi N, Miyao K, Takata F, Shuto H, Yamauchi A and Kataoka Y: Tumor necrosis factor-alpha mediates the blood-brain barrier dysfunction induced by activated microglia in mouse brain microvascular endothelial cells. J Pharmacol Sci 112: 251-254, 2010

82. Tremblay MÈ, Stevens B, Sierra A, Wake H, Bessis A and Nimmerjahn A: The role of microglia in the healthy brain. J Neurosci 31: 16064-16069, 2011

83. Attwell D, Buchan AM, Charpak S, Lauritzen M, Macvicar BA and Newman EA: Glial and neuronal control of brain blood flow. Nature 468: 232-243, 2010.

84. Simard M, Arcuino G, Takano T, Liu QS and Nedergaard M Signaling at the gliovascular interface. J Neurosci 23 9254-9262, 2003

85. Wang X, Lou N, Xu Q, Tian GF, Peng WG, Han X, Kang J, Takano T and Nedergaard M: Astrocytic Ca2+ signaling evoked by sensory stimulation in vivo. Nat Neurosci 9: 816-823, 2006.

86. Harder DR, Zhang C and Gebremedhin D: Astrocytes function in matching blood flow to metabolic activity. News Physiol Sci 17: 27-31, 2002

87. Nash B, Thomson CE, Linington C, Arthur AT, McClure JD, McBride MW and Barnett SC: Functional duality of astrocytes in myelination. J Neurosci 31: 13028-13038, 2011.

88. Kim KS: Pathogenesis of bacterial meningitis: From bacteraemia to neuronal injury. Nat Rev Neurosci 4: 376-385, 2003.

89. Merrill JE and Benveniste EN: Cytokines in inflammatory brain lesions: Helpful and harmful. Trends Neurosci 19: 331-338, 1996.

90. van Furth AM, Roord JJ and van Furth R: Roles of proinflammatory and anti-inflammatory cytokines in pathophysiology of bacterial meningitis and effect of adjunctive therapy. Infect Immun 64: 4883-4890, 1996.

91. Barichello T, dos Santos I, Savi GD, Simões LR, Silvestre T, Comim CM, Sachs D, Teixeira MM, Teixeira AL and Quevedo J: TNF-alpha, IL-1beta, IL-6, and cinc-1 levels in rat brain after meningitis induced by Streptococcus pneumoniae. J Neuroimmunol 221: 42-45, 2010.

92. Barichello T, Generoso JS, Collodel A, Moreira AP and Almeida SM: Pathophysiology of acute meningitis caused by Streptococcus pneumoniae and adjunctive therapy approaches. Arq Neuropsiquiatr 70: 366-372, 2012.

93. Ichiyama T, Isumi H, Yoshitomi T, Nishikawa M, Matsubara T and Furukawa S: NF-kappaB activation in cerebrospinal fluid cells from patients with meningitis. Neurol Res 24: 709-712, 2002.

94. Gerber J, Böttcher T, Hahn M, Siemer A, Bunkowski S and Nau R: Increased mortality and spatial memory deficits in TNF-alpha-deficient mice in ceftriaxone-treated experimental pneumococcal meningitis. Neurobiol Dis 16: 133-138, 2004.

95. Koedel U, Winkler F, Angele B, Fontana A, Flavell RA and Pfister HW: Role of Caspase-1 in experimental pneumococcal meningitis: Evidence from pharmacologic Caspase inhibition and Caspase-1-deficient mice. Ann Neurol 51: 319-329, 2002.

96. Saukkonen K, Sande S, Cioffe C, Wolpe S, Sherry B, Cerami A and Tuomanen E: The role of cytokines in the generation of inflammation and tissue damage in experimental gram-positive meningitis. J Exp Med 171: 439-448, 1990.

97. Zwijnenburg PJ, van der Poll T, Florquin S, Roord JJ and van Furth AM: Interleukin-10 negatively regulates local cytokine and chemokine production but does not influence antibacterial host defense during murine pneumococcal meningitis. Infect Immun 71: 2276-2279, 2003

98. Barichello T, Fagundes GD, Generoso JS, Paula Moreira A, Costa CS, Zanatta JR, Simões LR, Petronilho F, Dal-Pizzol F, Carvalho Vilela M and Lucio Teixeira A: Brain-blood barrier breakdown and pro-inflammatory mediators in neonate rats submitted meningitis by Streptococcus pneumoniae. Brain Res 1471: 162-168, 2012 . 
99. Gruol DL and Nelson TE: Physiological and pathological roles of interleukin-6 in the central nervous system. Mol Neurobiol 15: 307-339, 1997.

100. van der Poll T, Keogh CV, Guirao X, Buurman WA, Kopf M and Lowry SF: Interleukin-6 gene-deficient mice show impaired defense against pneumococcal pneumonia. J Infect Dis 176: 439-444, 1997.

101. Paul R, Koedel U, Winkler F, Kieseier BC, Fontana A, Kopf M, Hartung HP and Pfister HW: Lack of IL-6 augments inflammatory response but decreases vascular permeability in bacterial meningitis. Brain 126: 1873-1882, 2003.

102. Glimåker M, Olcén P and Andersson B: Interferon-gamma in cerebrospinal fluid from patients with viral and bacterial meningitis. Scand J Infect Dis 26: 141-147, 1994.

103. McNeela EA, Burke A, Neill DR, Baxter C, Fernandes VE, Ferreira D, Smeaton S, El-Rachkidy R, McLoughlin RM, Mori A, et al: Pneumolysin activates the NLRP3 inflammasome and promotes proinflammatory cytokines independently of TLR4. PLoS Pathog 6: e1001191, 2010

104. Mitchell AJ, Yau B, McQuillan JA, et al: Inflammasome-dependent IFN- $\gamma$ drives pathogenesis in Streptococcus pneumoniae meningitis. J Immunol 189: 4970-4980, 2012.

105. Howard M, O'Garra A, Ishida H, de Waal Malefyt R and de Vries J: Biological properties of interleukin 10. J Clin Immunol 12: 239-247, 1992

106. Kornelisse RF, Savelkoul HF, Mulder PH, Suur MH, van der Straaten PJ, van der Heijden AJ, Sukhai RN, Hählen K, Neijens HJ and de Groot R: Interleukin-10 and soluble tumor necrosis factor receptors in cerebrospinal fluid of children with bacterial meningitis. J Infect Dis 173: 1498-1502, 1996.

107. Koedel U, Bernatowicz A, Frei K, Fontana A and Pfister HW: Systemically (but not intrathecally) administered IL-10 attenuates pathophysiologic alterations in experimental pneumococcal meningitis. J Immunol 157: 5185-5191, 1996.

108. Laichalk LL, Danforth JM and Standiford TJ: Interleukin-10 inhibits neutrophil phagocytic and bactericidal activity. FEMS Immunol Med Microbiol 15: 181-187, 1996.

109. Sanjabi S, Zenewicz LA, Kamanaka M and Flavell RA: Anti-inflammatory and pro-inflammatory roles of TGF-beta, IL-10, and IL-22 in immunity and autoimmunity. Curr Opin Pharmacol 9: 447-453, 2009.

110. Li MO and Flavell RA: Contextual regulation of inflammation: A duet by transforming growth factor-beta and interleukin-10. Immunity 28: 468-476, 2008 .

111. Suzumura A, Sawada M, Yamamoto H and Marunouchi T: Transforming growth factor-beta suppresses activation and proliferation of microglia in vitro. J Immunol 151: 2150-2158, 1993

112. Ledeboer A, Brevé JJ, Poole S, Tilders FJ and Van Dam AM: Interleukin-10, interleukin-4, and transforming growth factor-beta differentially regulate lipopolysaccharide-induced production of pro-inflammatory cytokines and nitric oxide in co-cultures of rat astroglial and microglial cells. Glia 30: 134-142, 2000.

113. Levy N, Milikovsky DZ, Baranauskas G, Vinogradov E, David Y, Ketzef M, Abutbul S, Weissberg I, Kamintsky L, Fleidervish I, et al: Differential TGF- $\beta$ signaling in glial subsets underlies IL-6-mediated epileptogenesis in mice. J Immunol 195: 1713-1722, 2015.

114. Malipiero U, Koedel U, Pfister HW, Levéen P, Bürki K, Reith W and Fontana A: TGFbeta receptor II gene deletion in leucocytes prevents cerebral vasculitis in bacterial meningitis. Brain 129 2404-2415, 2006.

115. Gerber J and Nau R: Mechanisms of injury in bacterial meningitis. Curr Opin Neurol 23: 312-318, 2010.

116. Ostergaard C, Yieng-Kow RV, Larsen CG, Mukaida N, Matsushima K, Benfield T, Frimodt-Møller N, Espersen F, Kharazmi A and Lundgren JD: Treatment with a monocolonal antibody to IL-8 attenuates the pleocytosis in experimental pneumococcal meningitis in rabbits when given intravenously, but not intracisternally. Clin Exp Immunol 122: 207-211, 2000.

117. Spanaus KS, Nadal D, Pfister HW, Seebach J, Widmer U, Frei $\mathrm{K}$, Gloor S and Fontana A: C-X-C and C-C chemokines are expressed in the cerebrospinal fluid in bacterial meningitis and mediate chemotactic activity on peripheral blood-derived polymorphonuclear and mononuclear cells in vitro. J Immunol 158 1956-1964, 1997

118. Prinz M, Kann O, Draheim HJ, Schumann RR, Kettenmann H, Weber JR and Hanisch UK: Microglial activation by components of gram-positive and -negative bacteria: Distinct and common routes to the induction of ion channels and cytokines. J Neuropathol Exp Neurol 58: 1078-1089, 1999.
119. Hanisch UK, Prinz M, Angstwurm K, Häusler KG, Kann O, Kettenmann $\mathrm{H}$ and Weber JR: The protein tyrosine kinase inhibitor AG126 prevents the massive microglial cytokine induction by pneumococcal cell walls. Eur J Immunol 31: 2104-2115, 2001.

120. Carlos TM and Harlan JM: Leukocyte-endothelial adhesion molecules. Blood 84: 2068-2101, 1994.

121. Polfliet MM, Zwijnenburg PJ, van Furth AM, van der Poll T, Döpp EA, Renardel de Lavalette C, van Kesteren-Hendrikx EM, van Rooijen N, Dijkstra CD and van den Berg TK: Meningeal and perivascular macrophages of the central nervous system play a protective role during bacterial meningitis. J Immunol 167: 4644-4650, 2001.

122. Stanimirovic D and Satoh K: Inflammatory mediators of cerebral endothelium: A role in ischemic brain inflammation. Brain Pathol 10: 113-126, 2000

123. Winkler F, Kastenbauer S, Koedel U and Pfister HW: Role of the urokinase plasminogen activator system in patients with bacterial meningitis. Neurology 59: 1350-1355, 2002.

124. Nagase H, Visse R and Murphy G: Structure and function of matrix metalloproteinases and TIMPs. Cardiovasc Res 69: $562-573,2006$

125. Leppert D, Leib SL, Grygar C, Miller KM, Schaad UB and Holländer GA: Matrix metalloproteinase (MMP)-8 and MMP-9 in cerebrospinal fluid during bacterial meningitis: Association with blood-brain barrier damage and neurological sequelae. Clin Infect Dis 31: 80-84, 2000.

126. Barichello T, Generoso JS, Simões LR, Elias SG and Quevedo J: Role of oxidative stress in the pathophysiology of pneumococcal meningitis. Oxid Med Cell Longev 2013: 371465, 2013.

127. Koedel U and Pfister HW: Oxidative stress in bacterial meningitis. Brain Pathol 9: 57-67, 1999.

128. Nathan $\mathrm{C}$ and Shiloh MU: Reactive oxygen and nitrogen intermediates in the relationship between mammalian hosts and microbial pathogens. Proc Natl Acad Sci USA 97: 8841-8848, 2000.

129. Aycicek A, Iscan A, Erel O, Akcali M and Ocak AR: Oxidant and antioxidant parameters in the treatment of meningitis. Pediatr Neurol 37: 117-120, 2007.

130. Braun JS, Sublett JE, Freyer D, Mitchell TJ, Cleveland JL, Tuomanen EI and Weber JR: Pneumococcal pneumolysin and $\mathrm{H}(2) \mathrm{O}(2)$ mediate brain cell apoptosis during meningitis. J Clin Invest 109: 19-27, 2002.

131. Beckman JS and Koppenol WH: Nitric oxide, superoxide, and peroxynitrite: The good, the bad, and ugly. Am J Physiol 271: C1424-C1437, 1996.

132. Pacher P, Beckman JS and Liaudet L: Nitric oxide and peroxynitrite in health and disease. Physiol Rev 87: 315-424, 2007.

133. Halliwell B, Zhao K and Whiteman M: Nitric oxide and peroxynitrite. The ugly, the uglier and the not so good: A personal view of recent controversies. Free Radic Res 31: 651-669, 1999.

134.Gutteridge JM: Lipid peroxidation and antioxidants as biomarkers of tissue damage. Clin Chem 41: 1819-1828, 1995

135. Maeda H, Okamoto T and Akaike T: Human matrix metalloprotease activation by insults of bacterial infection involving proteases and free radicals. Biol Chem 379: 193-200, 1998.

136. Filep JG, Beauchamp M, Baron C and Paquette Y: Peroxynitrite mediates IL-8 gene expression and production in lipopolysaccharide-stimulated human whole blood. J Immunol 161 $5656-5662,1998$.

137. Kastenbauer S, Koedel U, Becker BF and Pfister HW: Pneumococcal meningitis in the rat: Evaluation of peroxynitrite scavengers for adjunctive therapy. Eur J Pharmacol 449: 177-181, 2002.

138. Klein M, Koedel U and Pfister HW: Oxidative stress in pneumococcal meningitis: A future target for adjunctive therapy? Prog Neurobiol 80: 269-280, 2006.

139. Kastenbauer S, Koedel U and Pfister HW: Role of peroxynitrite as a mediator of pathophysiological alterations in experimental pneumococcal meningitis. J Infect Dis 180: 1164-1170, 1999.

140. Østergaard C, Leib SL, Rowland I and Brandt CT: Bacteremia causes hippocampal apoptosis in experimental pneumococcal meningitis. BMC Infect Dis 10: 1, 2010.

141. Nau R, Soto A and Brück W: Apoptosis of neurons in the dentate gyrus in humans suffering from bacterial meningitis. J Neuropathol Exp Neurol 58: 265-274, 1999.

142. Grandgirard D and Leib SL: Strategies to prevent neuronal damage in paediatric bacterial meningitis. Curr Opin Pediatr 18: $112-118,2006$ 
143. BermpohlD, Halle A,Freyer D, Dagand E, Braun JS, Bechmann I, Schröder NW and Weber JR: Bacterial programmed cell death of cerebral endothelial cells involves dual death pathways. J Clin Invest 115: 1607-1615, 2005.

144. Mitchell L, Smith SH, Braun JS, Herzog KH, Weber JR and Tuomanen EI: Dual phases of apoptosis in pneumococcal meningitis. J Infect Dis 190: 2039-2046, 2004.

145. Malipiero U, Koedel U, Pfister HW, Levéen P, Bürki K, Reith W and Fontana A: TGFb receptor II gene deletion in leucocytes prevents cerebral vasculitis in bacterial meningitis. Brain 129 2404-2415, 2006

146. Koedel U, Scheld WM and Pfister HW: Pathogenesis and pathophysiology of pneumococcal meningitis. Lancet Infect Dis 2 721-736, 2002.

147. Kastenbauer S and Pfister HW: Pneumococcal meningitis in adults: Spectrum of complications and prognostic factors in a series of 87 cases. Brain 126: 1015-1025, 2003.

148. Weisfelt M, van de Beek D, Spanjaard L, Reitsma JB and de Gans J: Clinical features, complications, and outcome in adults with pneumococcal meningitis: A prospective case series. Lancet Neurol 5: 123-129, 2006.

149. Müller M, Merkelbach S, Huss GP and Schimrigk K: Clinical relevance and frequency of transient stenoses of the middle and anterior cerebral arteries in bacterial meningitis. Stroke 26: 1399-1403, 1995

150. Weisfelt M, Determann RM, de Gans J, van der Ende A, Levi M, van de Beek D and Schultz MJ: Procoagulant and fibrinolytic activity in cerebrospinal fluid from adults with bacterial meningitis. J Infect 54: 545-550, 2007.

151. Vergouwen MD, Schut ES, Troost D and van de Beek D: Diffuse cerebral intravascular coagulation and cerebral infarction in pneumococcal meningitis. Neurocrit Care 13: 217-227, 2010

152. Møller K, Qvist T, Tofteng F, Sahl C, Sønderkaer S, Dethloff T, Knudsen GM and Larsen FS: Cerebral blood flow and metabolism during infusion of norepinephrine and propofol in patients with bacterial meningitis. Stroke 35: 1333-1339, 2004.

153. Møller K, Skinhøj P, Knudsen GM and Larsen FS: Effect of short-term hyperventilation on cerebral blood flow autoregulation in patients with acute bacterial meningitis. Stroke 31: 1116-1122, 2000

154. Barone FC and Feuerstein GZ: Inflammatory mediators and stroke: New opportunities for novel therapeutics. J Cereb Blood Flow Metab 19: 819-834, 1999.

155. Nau R, Gerber J, Bunkowski S and Brück W: Axonal injury, a neglected cause of CNS damage in bacterial meningitis. Neurology 62: 509-511, 2004.

156. Dénes A, Pradillo JM, Drake C, Sharp A, Warn P, Murray KN, Rohit B, Dockrell DH, Chamberlain J, Casbolt H, et al: Streptococcus pneumoniae worsens cerebral ischemia via interleukin 1 and platelet glycoprotein Ib $\alpha$. Ann Neurol 75: 670-683, 2014.

157. Prass K, Braun JS, Dirnagl U, Meisel C and Meisel A: Stroke propagates bacterial aspiration to pneumonia in a model of cerebral ischemia. Stroke 37: 2607-2612, 2006.

158.Xie W, Liu Q, Feng J and Fang S: A case of bacterial meningitis complicated by venous sinus thrombosis. Neurol Sci 36 331-331, 2014

159. Panicio MI, Foresto RD, Mateus L, Monzillo PH, Alves MB and Silva GS: Pneumococcal meningitis, cerebral venous thrombosis, and cervical arterial dissection: A run of bad luck? Neurohospitalist 3: 20-23, 2013.

160. Srivastava AK, Kalita J, Haris M, Gupta RK and Misra UK: Radiological and histological changes following cerebral venous sinus thrombosis in a rat model. Neurosci Res 65: 343-346, 2009.

161. Coutinho JM, Gerritsma JJ, Zuurbier SM and Stam J: Isolated cortical vein thrombosis: Systematic review of case reports and case series. Stroke 45: 1836-1838, 2014.

162. Pomeroy SL, Holmes SJ, Dodge PR and Feigin RD: Seizures and other neurologic sequelae of bacterial meningitis in children. N Engl J Med 323: 1651-1657, 1990.

163. Murthy JM and Prabhakar S: Bacterial meningitis and epilepsy. Epilepsia 49 (Suppl 6): S8-S12, 2008.

164.Zoons E, Weisfelt M, de Gans J, Spanjaard L, Koelman JH, Reitsma JB and van de Beek D: Seizures in adults with bacterial meningitis. Neurology 70: 2109-2115, 2008

165.Lu CH, Huang CR, Chang WN, Chang CJ, Cheng BC, Lee PY, Lin MW and Chang HW: Community-acquired bacterial meningitis in adults: The epidemiology, timing of appropriate antimicrobial therapy, and prognostic factors. Clin Neurol Neurosurg 104: 352-358, 2002.
166. Chin RF, Neville BG, Peckham C, Bedford H, Wade A and Scott RC; NLSTEPSS Collaborative Group: Incidence, cause, and short-term outcome of convulsive status epilepticus in childhood: Prospective population-based study. Lancet 368: 222-229, 2006.

167. Chin RF, Neville BG and Scott RC: Meningitis is a common cause of convulsive status epilepticus with fever. Arch Dis Child 90: 66-69, 2005.

168. Bar-Klein G, Cacheaux LP, Kamintsky L, Prager O, Weissberg I, Schoknecht K, Cheng P, Kim SY, Wood L, Heinemann U, et al: Losartan prevents acquired epilepsy via TGF- $\beta$ signaling suppression. Ann Neurol 75: 864-875, 2014.

169. Cacheaux LP, Ivens S, David Y, Lakhter AJ, Bar-Klein G, Shapira M, Heinemann U, Friedman A and Kaufer D: Transcriptome profiling reveals TGF-beta signaling involvement in epileptogenesis. J Neurosci 29: 8927-8935, 2009.

170. Ivens S, Kaufer D, Flores LP, Bechmann I, Zumsteg D, Tomkins O, Seiffert E, Heinemann U and Friedman A: TGF-beta receptor-mediated albumin uptake into astrocytes is involved in neocortical epileptogenesis. Brain 130: 535-547, 2007.

171. Seiffert E, Dreier JP, Ivens S, Bechmann I, Tomkins O, Heinemann U and Friedman A: Lasting blood-brain barrier disruption induces epileptic focus in the rat somatosensory cortex. J Neurosci 24: 7829-7836, 2004.

172. Vezzani A, French J, Bartfai T and Baram TZ: The role of inflammation in epilepsy. Nat Rev Neurol 7: 31-40, 2011.

173. Igarashi M, Saito R, Alford BR, Filippone MV and Smith JA: Temporal bone findings in pneumococcal meningitis. Arch Otolaryngol 99: 79-83, 1974

174. Külahli I, Oztürk M, Bilen C, Cüreoglu S, Merhametsiz A and Cağil N: Evaluation of hearing loss with auditory brainstem responses in the early and late period of bacterial meningitis in children. J Laryngol Otol 111: 223-227, 1997.

175. Klein M, Koedel U, Kastenbauer S and Pfister HW: Nitrogen and oxygen molecules in meningitis-associated labyrinthitis and hearing impairment. Infection 36: 2-14, 2008.

176. Klein M, Schmidt C, Kastenbauer S, Paul R, Kirschning CJ, Wagner H, Popp B, Pfister HW and Koedel U: MyD88-dependent immune response contributes to hearing loss in experimental pneumococcal meningitis. J Infect Dis 195: 1189-1193, 2007.

177. Aminpour S, Tinling SP and Brodie HA: Role of tumor necrosis factor-alpha in sensorineural hearing loss after bacterial meningitis. Otol Neurotol 26: 602-609, 2005

178. Berg S, Trollfors B, Hugosson S, Fernell E and Svensson E: Long-term follow-up of children with bacterial meningitis with emphasis on behavioural characteristics. Eur J Pediatr 161: 330-336, 2002.

179. Grimwood K, Anderson VA, Bond L, Catroppa C, Hore RL, Keir EH, Nolan T and Roberton DM: Adverse outcomes of bacterial meningitis in school-age survivors. Pediatrics 95: 646-656, 1995.

180. Skoog I, Wallin A, Fredman P, Hesse C, Aevarsson O, Karlsson I, Gottfries CG and Blennow K: A population study on blood-brain barrier function in 85-year-olds: Relation to Alzheimer's disease and vascular dementia. Neurology 50: 966-971, 1998.

181. Schroeter ML, Abdul-Khaliq H, Krebs M, Diefenbacher A and Blasig IE: Serum markers support disease-specific glial pathology in major depression. J Affect Disord 111: 271-280, 2008

182. Alesci S, Martinez PE, Kelkar S, Ilias I, Ronsaville DS, Listwak SJ, Ayala AR, Licinio J, Gold HK, Kling MA, et al: Major depression is associated with significant diurnal elevations in plasma interleukin-6 levels, a shift of its circadian rhythm, and loss of physiological complexity in its secretion: Clinical implications. J Clin Endocrinol Metab 90: 2522-2530, 2005.

183. Thomas AJ, Davis S, Morris C, Jackson E, Harrison R and O'Brien JT: Increase in interleukin-lbeta in late-life depression. Am J Psychiatry 162: 175-177, 2005. 